\title{
Morphologic Changes in Rat's Pineal Gland After Eliminating Retinal Photic Stimulation
}

\author{
Cambios Morfológicos en la Glándula Pineal de Ratas \\ Luego de la Eliminación de la Estimulación Fótica Retiniana
}

"Ignacio Roa Henriquez; "Iván Suazo Galdames; "Mario Cantín López \& *"Daniela Zavando Matamala

ROA, H. I.; SUAZO, G. I.; CANTÍN, L. M. \& ZAVANDO, M. D. Morphologic changes in rat's pineal gland after eliminating retinal photic stimulation.Int. J. Morphol., 26(3):665-668, 2008.

SUMMARY: Melatonin secretion from mammalian pineal glands is regulated by light stimulation by means of a complex neuroanatomical pathway that includes the retina, hypothalamic suprachiasmatic nucleus, intermediolateral nucleus of the thoracic spinal cord, and finally, the superior cervical ganglia. The purpose of this study was to analyze the changes in the pinealocytes and the blood vessel density of the pineal gland after eliminating photic stimulation in rats. Thirteen adult Sprague-Dawley rats were divided into 2 groups, Group I acted as control, and Group II was subjected to a retinal lesion, by means of alcohol injected bilaterally to both ocular bulbs. After 3 weeks, the glands of both groups were processed with hematoxilin-eosin (HE) and observed with an optic microscope. Group II results presented higher values in the number of pinealocytes and in the blood vessels observed. The differences with Group I was significant at $\mathrm{p}<0.01$. These results give an indirect evidence of the effect that photic stimulation suppression has in the pineal gland in rats.

KEY WORDS: Pineal gland; Rat; Photic stimulation; Pinealocytes.

\section{INTRODUCTION}

The pineal gland, also known as pineal body, is a medium and odd endocrine organ, which originates in the second month of intrauterine life (Macchi \& Bruce, 2004) as a diencephalon roof evagination with a conical shape (Bertolucci \& Foa, 2004), is aimed antero-posterior and rests on the path that separates the upper colliculus of the posterior wall of the third ventricle and is joined habenular and posterior commissures (Rouvière \& Delmas, 1999). It is covered by the pia mater which will form a capsule from which are projected by partitions which admit a large number of blood vessels these walls subsequently divided into lobules incomplete (Koshy \& Vettivel, 2001a, b; Gardner \& Hiatt, 2002; Junqueira \& Carneiro, 2003; Beltrán, 2003).

The pineal of mammals is innervated by sympathetic fibers originating from the superior cervical ganglia of the paravertebral chain (Beltran), this ganglia origin major differences arriving in the pineal under the name nervi conarii (Macchi \& Bruce; Cignolani \& Houssay, 2002).

The first component of the innervation path of the pineal gland is the retino-hypothalamic tract, which is projected from the retina to the ventrolateral suprachiasmatic nucleus between now travels towards the paraventricular hypothalamic nucleus, and in them towards intermediolateral cell column of the layers VII between T1 and T3 levels of the spinal cord through the medial pathway of the anterior brain (Moore, 1996). At this level are preganglionic neurons which make synapses at the upper cervical ganglion (Anderson et al., 2002).

Through this pathway, light regulates the activity of the pineal gland and the secretion of its main hormone, melatonin that deals with important functions in mammals, such as determining circadian rhythms (Korf et al., 2003). Additionally, melatonin is a geroprotector (Anisimov, 2003) and an antioxidant (Savaskan, 2002). It also exerts oncostatic effects (Lenoir et al., 2005); has an effect on gonadal action (Macchi \& Bruce; Olivares et al., 2003; Bustos-Obregon et al., 2007); and has an immunoprotective role (Arias et al., 2003). Melatonin treatment in degenerative diseases such as Alzheimer's (Zhu et al., 2004) has also been described.

\footnotetext{
* Unidad de Anatomía Normal, Facultad de Ciencias de la Salud, Universidad de Talca, Chile.

** Departamento de Estomatología, Facultad de Ciencias de la Salud, Universidad de Talca, Chile.
} 
The purpose of this study is to analyze morphological changes at the level of the pineal gland, after eliminating retinal function in rats.

\section{MATERIAL AND METHOD}

We used 13 male Sprague Dawley rats, adult females weighed 250 - 300 grams. These were acquired from the bioterio ANEXPA, Talca. Throughout the experimental period, the rats were housed in cages in the Laboratory of Anatomy at the Universidad de Talca, Chile. Light was maintained with cycles of 12/12 hours (light and dark), with heating and with a regular diet of pellets and drinking water ad libitum. Rats were divided into 2 groups:

Group I of 6 rats, as a control.

Group II of 7 rats were subjected to general anesthesia inhaled using ethyl ether in a camera. When the rats were at thoracoabdominal breathing and lacked movement of whiskers, they were considered under deep anesthesia. Once induced, bulbar conjunctiva was anesthetized with lidocaine $3 \%$, then in the absence of corneal reflex, retinal lesion was performed by injecting $0.5 \mathrm{ml}$ of alcohol ethyl to $100 \%$ in the vitreous chamber on a bilateral basis. After 3 weeks, culling was done through overdose inhalation of ethyl ether, then, the rats were decapitated for subsequent sampling. The heads were preserved in formalin $10 \%$ solution for 3 days,

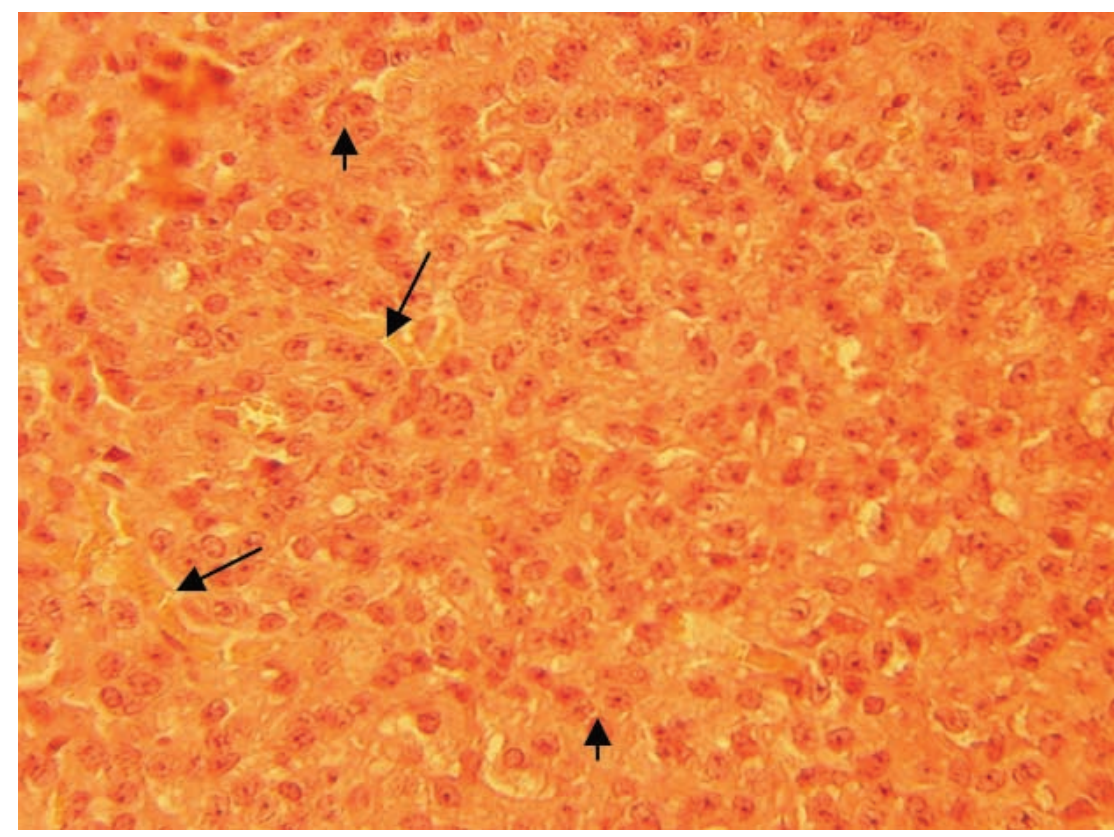

Fig 1. Microphotography of pineal gland in experimental group. Microcount method of blood vessels and the number of pinealocytes. Blood vessels are marked with arrows and arrow heads with pinealocytes (hematoxylin-eosin, magnified by 400X). after which decalcified bone cranial tissue was contained in a solution of nitric acid to $5 \%$ for 7 days. Then the pineal gland was obtained through microdissection using a $10^{\prime}$ increased lens. The pineal tissues were stored in bottles, individually and specifically labeled and fixed in $10 \%$ formalin, and processed for hematoxylin-eosin.

There were six semiseriated cuts $5 \mathrm{~mm}$ per pineal sample, each plate was observed using an optical microscope ZEISS, model 0.25 Standard (Germany), with different optical objectives $(3.2,10,20$, and $40 \mathrm{X})$ following the procedure proposed by Weidner et al. (1991) identifying vascular microdensity and identifying the areas of greatest vascularization (hotspot). With increased 40' plates were photographed, and were held on microcount method of blood vessels and the number of pinealocytes was determined (Fig. 1).

Data were analyzed by a single observer and by remeasurement method calculated through intraobserver matching.

Using the SPSS 11.5 program for Windows, descriptive statistics were calculated and statistically significant differences in average values were obtained in the control group and experimentally, applying t test with a $\mathrm{p}$ value $<0.01$.

\section{RESULTS}

A total of 78 cuts were obtained for analysis: 36 for Group I and 42 for Group II. Blood vessels recorded in the control group were an average of 5.35 (SD 0.7), higher values were observed in the experimental group with a mean of 12.43 (SD 1.1), differences were significant at $\mathrm{p}<0.01$. The average of pinealocytes counted in the control group was 345.22 (SD 142.6), values lower than for the experimental group, in which the average was 518.73 (SD 80.7). These differences were statistically significant at $p<0.01$. The descriptive statistics for the number of blood vessels and pinealocytes in the control and experimental groups are listed in Table I. The remeasurement results show a high level of intraobserver consistency $(\mathrm{k}=0.86)$. 
Table I. Descriptive statistical for the blood vessels and pynealocites number in control and experimental groups.

\begin{tabular}{llcccc}
\hline & Group & $\mathrm{n}$ & Mean & SD & Mean error \\
\hline Blood vessels & Control & 36 & 5.35 & 4.213 & 0.702 \\
& Experimental & 40 & 12.43 & 7.020 & 1.110 \\
Pynealocites & Control & 36 & 345.22 & 142.680 & 23.780 \\
& Experimental & 40 & 518.73 & 80.700 & 12.760 \\
\hline
\end{tabular}

\section{DISCUSSION}

In the path of gland stimulation, light is very important although this relationship is not linear, as expressed by Zeitzer et al. (2000). The absence of light or its low intensity leads pinealocytes to produce and release melatonin into the body. In the present study, we analyzed the changes in the vascular density and cells associated with the elimination of photic stimulation in rats by means of retinal damage. By histological analysis of the samples obtained, 3 weeks elicited important findings, such as an increase in the vascular density as well as in the density of pinealocytes. The latter agreed with the findings of Kus et al. (2004), which observed an increase in the number of pinealocytes in rats subjected to constant darkness compared to groups subjected to constant light and a control group. For Koshy \& Vettivel (2001a, b), in humans, the density of pinealocytes is higher in younger individuals and decreases over the years in subjects' equivalent levels of light stimulation. In our study, significant morphologic changes were observed in pineal glands of rats with retinal damage. This finding provides an indirect evidence of a possible increase in the secretion of melatonin. With respect to biological effects and important clinical implications, for Jean-Louis et al. (2005), lesions in the retina and the optic nerve alter the rhythms of melatonin secretion.

ROA, H. I.; SUAZO, G. I.; CANTíN, L. M. \& ZAVANDO, M. D. Cambios morfológicos en la glándula pineal de ratas luego de la eliminación de la estimulación fótica retiniana. Int. J. Morphol., 26(3):665-668, 2008.

RESUMEN: La secreción de melatonina por parte de glándula pineal de los mamíferos es regulada por la estimulación luminosa mediante complejas vías neuroanatómicas que incluyen la retina, el núcleo supraquiasmático hipotalámico, el núcleo intermediolateral de la médula torácica y finalmente el ganglio cervical superior. El propósito de este estudio fue analizar los cambios en la densidad de pinealocitos y vasos sanguíneos de la glándula pineal, luego de eliminar la estimulación fótica en ratas. Se utilizaron 13 ratas adultas Sprague Dawley divididas en 2 grupos, Grupo I actuó como control, y el Grupo II fue sometido a una lesión retiniana, por medio de alcoholización bilateral de ambos bulbos oculares. Luego de tres semanas las glándulas de ambos grupos fueron procesadas para hematoxilina-eosina y observadas al microscopio óptico. El grupo II presentó valores mayores en el número de pinealocitos y de vasos sanguíneos observados, las diferencias con el Grupo I fueron significativas con $p<0.01$. Estos resultados entregan una evidencia indirecta del efecto que la supresión de la estimulación fótica tiene en la glándula pineal en ratas.

PALABRAS CLAVE: Glándula pineal; Rata; Estimulación fótica; Pinealocitos.

\section{REFERENCES}

Anderson, C. R.; Penkethman, S. L.; Berger, A. J.; Mcallen, R. M. \& Murphy, S. M. Control of postganglionic neurone phenotype by the rat pineal gland. Neuroscience, 109:329-37, 2002.

Anisimov, W. Effect of Exogenous Melatonin - A Review Toxicologic. Pathology, 31:589-603, 2003.

Arias, J.; Melean, E.; Valero, N.; Pons, H.; Chacín-Bonilla, L.; Larreal, Y. \& Bonilla, E. Efecto de la Melatonina en la
Proliferación Linfocitaria y la Producción de Interleucina 2 (IL-2) e Interleucina 1 Beta (IL-1b) en Esplenocitos de Ratones. Invest. Clín., 44:41-50, 2003.

Beltrán, D. D. Estudio comparativo de la organización estructural y funcional de la pineal en la especie ovina. Tesis doctoral, España, Universidad de Valencia, 2003.

Bertolucci, C. \& Foa, A. Extraocular photoreception and circadian entrainment in nonmammalian vertebrales. 
Chronobiol. Int., 21:501-19, 2004.

Bustos-Obregon, E.; Del Rio, F. C. \& Sarabia, L. Morphometric Analysis of Mice Testicular Tubules after Administration of Malathion and Maca. Int. J. Morphol., 25:245-8, 2007.

Cignolani, H. E. \& Houssay, A. B. Fisiología Médica de Houssay. $7^{\text {a }}$ Ed. Editorial El Ateneo, Buenos aires, 2002. p. 632-6; 1012-4.

Gardner, L. P. \& Hiatt, J. L. Texto y Atlas de Histología. $2^{\mathrm{a}}$ Ed. Editorial McGraw-Hill Interamericana, Buenos Aires, 2002. Pp.309-10.

Jean-Louis, G.; Kripke, D. F.; Elliott, J. A.; Zizi, F.; Wolintz, A. H. \& Lazzaro, D. R. Daily illumination exposure and melatonin: influence of ophthalmic dysfunction and sleep duration. J. Circadian Rhythms, 3:13, 2005.

Junqueira, L. C. \& Carneiro, J. Basic Histology: Text \& Atlas. $10^{\text {th }}$ Edition. New York, McGraw-Hill/Appleton \& Lange, 2003. Pp. 429-30.

Korf, H. W.; Von Gall, C. \& Stehle, J. The circadian system and melatonin: lessons from rats and mice. Chronobiol. Int.,; 20:697-710, 2003.

Koshy, S. \& Vettivel, S. K. Varying appearances of calcification in human pineal gland: a light microscopic study. J. Anat. Soc. India, 50:17-8, 2001 a.

Koshy, S. \& Vettivel, S. K. Melanin Pigments in Human Pineal Gland. J. Anat. Soc. India, 50:122-6, $2001 \mathrm{~b}$.

Kus, I.; Sarsilmaz, M.; Ozen, O. A.; Turkoglu, A. O.; Pekmez, H.; Songur, A. \& Kelestimur, H. Light and electron microscopic examination of pineal gland in rats exposed to constant light and constant darkness. Neuro. Endocrinol. Lett., 25:102-8, 2004.

Lenoir, V.; de Jonage-Canonico, M. B.; Perrin, M. H.; Martin, A.; Scholler, R. \& Kerdelhue, B. Preventive and curative effect of melatonin on mammary carcinogenesis induced by dimethylbenz[a]anthracene in the female SpragueDawley rat. Breast Cancer Res., 7:470-6, 2005.

Macchi, M. M. \& Bruce, J. N. Human pineal physiology and functional significance of melatonin. Front. Neuroendocrinol., 25:177-95, 2004.

Moore, R. Neural control of the pineal gland. Behav. Brain Res., 73:125-30, 1996.
Olivares, P. A.; Bustos-Obregon, E.; Castillo, A. V. \& Zúñiga, R. O. Variaciones del funcionamiento testicular en Octopus mimus adultos. Int. J. Morphol., 21:315-23, 2003.

Rouvière, H. \& Delmas, A. Anatomía Humana Descriptiva, Topográfica y Funcional. 10 . Ed. Barcelona, Editorial Masson, 1999. V. 3.

Savaskan, E. Melatonin in aging and neurodegeneration. Drug. Dev. Res., 56:482-90, 2002.

Zeitzer, J. M.; Dijk, D. J.; Kronauer, R.; Brown, E. \& Czeisler, C. Sensitivity of the human circadian pacemaker to nocturnal light: melatonin phase resetting and suppression. J. Physiol., 526:695-702, 2000.

Zhu, L. Q.; Wang, S. H.; Ling, Z. Q.; Wang, D. L. \& Wang, J.Z. Effect of inhibiting melatonin biosynthesis on spatial memory retention and tau phosphorylation in rat. $J$. Pineal. Res., 37:71-7, 2004.

Correspondence to:

Prof. Dr. Iván Suazo Galdames

Unidad de Anatomía Normal

Universidad de Talca

Avenida Lircay s/n oficina $\mathrm{N}^{\circ} 104$

Talca - CHILE

Email: isuazo@utalca.cl

Received: 05-01-2008

Accepted: 22-07-2008 